\section{Multifaceted media campaign focuses attention on persons without health insurance in the United States of America ${ }^{1}$}

Key words: mass media; public opinion; insurance, health; medically uninsured; United States.

\footnotetext{
Based on: Covering the Uninsured. About Cover the Uninsured Week [Web page]. Available at: http://covertheuninsuredweek.org/ about/. Accessed 18 June 2003.
}

While the United States of America spends more on health care than any other nation in the world, tens of millions of persons in the country go without health insurance coverage every year, endangering the health of families and individuals and leading to economic losses for the nation. The plight of those uninsured persons was the focus of an intensive and extensive media campaign in early 2003, culminating in a series of special events during the "Cover the Uninsured Week," which ran from 10 March through 16 March.

The weeklong series of national and local activities was organized by a coalition that included the Robert Wood Johnson Foundation, two other major charitable foundations, some 160 other national organizations, and around 700 local groups in the United States. The various sectors represented included business, labor, health care, political, academic, and religious. Among the medical, health care, and public health groups involved in the coalition were the American Medical Association, American Nurses Association, Health Insurance Association of America, American Hospital Association, American Academy of Family Physicians, American Academy of Pediatrics, American Cancer Society, American Medical Student Association, American Public Health Association, Association of Schools of Public Health, and National Hispanic Medical Association.

The goals for the Cover the Uninsured Week included raising public awareness of the plight of uninsured persons in the United States; demonstrating broad support for action on the issue; generating media attention for the issue, both nationally and in communities across the country; and creating a single rallying point for groups and individuals working to extend health care coverage to the uninsured.

Out of a population of some 288 million persons in the United States, more than 41 million of them do not have health care insurance. About $62 \%$ of persons in the United States receive private health insurance as a benefit from their employer or their spouse's employer, with the employer often subsidizing some part of the cost of that insurance coverage. One public program, Medicare, covers nearly all individuals age 65 or older, and another public program, Medicaid, covers many low-income persons in the United States. Of those without health insurance, more than $80 \%$ belong to families where at least one person has paid employment, but many of those workers are in low-wage jobs or work for smaller businesses, where they are less 


\section{Expanding coverage to those without health insurance in the United States would be cost-effective}

The value of what the United States loses because of the poorer health and earlier death experienced by the 41 million residents of the country who lack health insurance is estimated to be US\$ 65 billion to US\$ 130 billion every year, according to a first-ever economic analysis of the costs of uninsurance for the nation overall. That cost could be recouped by extending health coverage to all persons in the United States, according to a report entitled Hidden Costs, Value Lost: Uninsurance in America. The report was issued in June 2003 by the Institute of Medicine, which is a private, nonprofit institution that provides health policy advice under a charter that the United States Congress has granted to the National Academy of Sciences.

The report looks at the health policy of the United States within a cost-benefit framework and applies the same approach that agencies of the Government of the United States use to determine whether the benefits of reducing a particular risk or harm justify the costs to society. The estimated US $\$ 65$ billion to US\$ 130 billion is the value of improved health that could be realized each year by providing health insurance coverage to all the persons in the country.

The report employed the concept of "health capital" to estimate the value that would be gained if health insurance were extended to all persons in the country. In monetary terms, health capital represents the value of an individual's health over future years of life. The differences in health status and life spans between the uninsured and otherwise similar people with coverage represents the value of health capital lost due to being uninsured.
Families and individuals without insurance face increased financial risk and uncertainty and other burdens as well. For example, in comparison to insured children, uninsured children are more likely to miss days of schooling and to lag behind in their educational achievements and overall development, which can affect eventual educational attainment, earning capacity, and longterm health. For adults, being without insurance can lead to illness, lost days of work, and reduced income.

The estimated value of improved health that an uninsured individual would gain with each year of coverage ranges between US\$ 1645 and US\$ 3280 annually. The aggregate value of US\$ 65 billion to US\$ 130 billion that could be realized for the entire population likely exceeds the US\$34 billion to US\$ 69 billion that it is estimated it would cost to provide the uninsured with the additional health services that they would use if they obtained insurance coverage and used the same amount and kind of services as the insured.

This report is the fifth in a series produced by the Institute of Medicine on the consequences of uninsurance in the United States. The series is intended to contribute to a more informed public debate about health care coverage. The committee's sixth and final report in the series will identify promising strategies for addressing the problem of uninsurance.

The Hidden Costs report is available for purchase from the National Academies Press, 500 Fifth Street, N.W., Lockbox 285, Washington, D.C. 20055, United States of America; telephone: (202) 334-3313; and fax: (202) 334-2451. The report can also be read page by page for free on the Web site of the National Academies Press, at http://www.nap.edu. likely to receive a health insurance benefit from their employer. Lacking insurance varies by ethnic group in the United States: 19\% of African-Americans are uninsured, as are $33 \%$ of Latinos.

Because the majority of health care in the United States is delivered by private providers, persons without health insurance often find it hard to obtain needed health care services. A small number of hospitals and clinics provide care for free, but those facilities often have limited hours or long waiting periods and may not be equipped to handle complicated illnesses. As a result, many uninsured persons delay seeking treatment or preventive care until they are facing an emergency, or it is too late.
For example, uninsured women who develop breast cancer are twice as likely to die as are women who have insurance coverage. Uninsured men are nearly twice as likely to be diagnosed with colon cancer at a later stage as are men with insurance. When a diagnosis comes too late to save an uninsured patient, that person's family can be left with debts that will take years to pay off. Other expenses are shifted to the larger society. When families are unable to pay money they owe to hospitals, the hospitals and insurance companies pass the costs on to employers and their employees in terms of higher insurance premium and higher out-of-pocket costs. The value of what the United States loses because of 
the poorer health and earlier death experienced by the 41 million residents of the country who lack health insurance is estimated to be US\$ 65 billion to US\$ 130 billion every year, according to a recently issued report (see sidebar entitled "Expanding coverage to those without health insurance in the United States would be cost-effective").

\section{DIFFERENT ACTIVITIES EACH DAY OF THE WEEK}

Each day of Cover the Uninsured Week concentrated on a different type of activity. The focus on Monday, 10 March, was "town hall" meetings. Many of those local, communitywide events began with a proclamation from a local or state elected official. The meetings brought together local, state, and federal elected officials; representatives from local Cover the Uninsured Week organizations; uninsured persons; the general public; and the news media. Each event served as a platform for highlighting the national Cover the Uninsured Week effort and announcing the week's local activities to the media and the general public. There were 74 town hall meetings held across the country.

The Tuesday activities were centered on university and college campuses. A total of 78 medical, dental, public health, and nursing schools conducted large, schoolwide teaching events about the plight of the uninsured and presented discussions of various ways to expand health coverage. A special teaching guide developed for the Week served as the basis for the campus discussions. The guide covered such topics as the prevalence and demographics of persons who lack health insurance, health consequences of going without coverage, and policy options for providing coverage for uninsured persons.

There were more than 550 "health fairs" across the nation on Wednesday, with physicians, nurses, dentists, hospitals, community health centers, and clinics providing free health screenings and services and enrolling eligible uninsured families and children into public health-coverage programs. Another event on that day was the release of a report on a survey of more than 1300 emergency physicians and their views on the plight of uninsured individuals. Eighty-one percent of the respondents said they believe that persons without health coverage are more likely to die prematurely than patients who have health insurance.

On Thursday, local leaders from business and labor organizations gathered together at 41 joint events to highlight the interest that those two sectors share in making certain that all persons in the United States have access to affordable health coverage. The results of a survey of 600 large and small businesses in the United States were also released. More than $70 \%$ of the employers said they expected the number of uninsured persons in the United States to continue growing over the coming decade. While the businesses said they remain strongly committed to trying to provide health insurance coverage for their workers, $92 \%$ of the firms said that in 2004 they expect to increase the amount that their employees would have to pay for their share of health insurance premiums.

The activities on Friday through Sunday focused on events organized by various religious groups. Seventy-three interfaith prayer breakfasts for religious leaders were held on Friday morning. Religious leaders in some congregations encouraged their congregants to reflect and act on the moral imperative to help the uninsured. The leaders of nine major religious groups-including Christians, Jews, and Moslems-issued a joint letter expressing concern for persons without health insurance and calling on others to help seek solutions to the problem.

The Cover the Uninsured Week coalition also conducted outreach activities with the entertainment industry. The Robert Wood Johnson Foundation organized a symposium for television script writers in Los Angeles early in 2003 to discuss the plight of uninsured persons and suggest ways that TV drama programs could include the issue in their story lines. Seven programs did mention the subject in their shows broadcast during Cover the Uninsured Week (1). In an episode of "ER," a nighttime drama seen by some 21 million viewers each week, most of the patients coming into the hospital's emergency room did not have health insurance coverage. In "Passions," a daytime soap opera, a woman coming home from the hospital needed nursing care but didn't have the coverage to pay for it. A similar approach, of working health messages into television dramas, has been applied in a number of countries around the world, such as with the issue of family planning (2)

With some Hollywood actors, the Robert Wood Johnson Foundation did something akin to what the National Cancer Institute (NCI) of Brazil had done with the actress who portrayed a character in a Brazilian soap opera who was ill with leukemia (3) In Brazil, the NCI persuaded the actress to record a public service announcement for a bone marrow donation program that the $\mathrm{NCI}$ was promoting. At the urging of the Robert Wood Johnson Foundation, several Hollywood actors recorded informational public services announcements on the insurance problem that were broadcast during Cover the Uninsured Week.

In total, more than 880 events related to Cover the Uninsured Week were held, in all 50 of the states as well as Washington, D.C. Media coverage 
was extensive, with over 3000 television, radio, newspaper, and magazine stories appearing. Two former presidents of the United States, Republican Gerald Ford and Democrat Jimmy Carter, served as the Honorary Co-Chairs for the Week. Nearly 800000 Cover the Uninsured Week promotional brochures, postcards, posters, and buttons were distributed to organizations and individuals across the country. Some 170000 persons visited the Web site for Cover The Uninsured Week.

The Cover the Uninsured Week activities were a continuation of efforts begun several years earlier by the Robert Wood Johnson Foundation and other groups. In January 2000 there was a national conference held in Washington, D.C., in which organizations presented specific proposals for decreasing the number of persons in the United States who lack health insurance. Between November 2000 and January 2001, seven meetings were held across the country in which local representatives from national organizations shared the stage with uninsured residents and federal, state, and local officials to discuss proposals for extending health care coverage to the uninsured. During March 2001, "town hall" meetings were held at more than 300 hospital sites across the United States. A moderated debate among members of the United States Congress was downlinked by satellite to each of those locations, and each site held its own discussions as well.

\section{AN ONGOING ISSUE FOR THE UNITED STATES}

Health insurance may become a major issue in the 2004 elections for the president of the United States. For example, four of the candidates competing for the nomination of the Democratic Party have proposed dramatic changes in the health care system in the United States in order to provide coverage for many of the persons without health insurance (4).

Some individual states have also taken steps of their own to try to solve the problem. In June 2003 the legislature of Maine, a state in the northeastern United States with a population of some 1.3 million, passed a law that would establish the first universal health insurance program in the United
States. Under the new law, by 2009, affordable health insurance would be available to all the residents of the state. Now, at any given point during the year, some 136000 of the state's residents lack health insurance coverage (5).

More information about the various efforts to provide health insurance coverage for all persons in the United States is available from the Cover the Uninsured Web site at http://covertheuninsuredweek. org and from the Web site of the Robert Wood Johnson Foundation at http://www.rwjf.org.

\section{SINOPSIS}

\section{Campaña mediática multifacética centra su atención en personas que no tienen seguro de salud en los Estados Unidos de América}

De una población de alrededor de 288 millones de personas que viven en los Estados Unidos de América, más de 41 millones no poseen seguro de salud, lo que pone en peligro la salud de familias y personas y provoca pérdidas económicas al país. La difícil situación de esas personas sin seguro fue el centro de una amplia e intensa campaña de los medios de comunicación masiva a principios del año 2003, la cual culminó en varios eventos nacionales y locales durante la llamada "Semana por el Aseguramiento de los no Asegurados", que transcurrió del 10 al 16 de marzo. Cada día de esa semana se dedicó a un tipo de actividad diferente. El lunes 10 de marzo se dedicó a reuniones locales con toda la comunidad. El martes, las actividades se centraron en las universidades. El miércoles se celebraron más de 550 "ferias de salud" por todo el país, con la participación de médicos, estomatólogos, personal de enfermería, hospitales, centros de salud comunitarios y clinicas, que brindaron sus servicios y realizaron tamizajes gratuitamente. Además, inscribieron a las familias y niños sin seguro de salud en los programas públicos de aseguramiento para los cuales eran elegibles. El jueves, líderes locales, tanto comerciantes como jefes de organizaciones laborales, resaltaron el interés que esos dos sectores comparten en aras de lograr que todas las personas que viven en los Estados Unidos puedan estar protegidas por un seguro de salud al alcance de sus posibilidades. Las actividades realizadas desde el viernes hasta el domingo se centraron en eventos organizados por varios grupos religiosos. La falta de seguro de salud de millones de personas en los Estados Unidos debe mantenerse como tema de actualidad en el país y debe ser parte de las campañas presidenciales del 2004.

\section{REFERENCES}

1. McGinley L, Nelson E. Not just for cars: issues get TV placement. Wall Street Journal 2003 March 4:B1.

2. Hagerman E. As the Third World turns. World Watch 1991;4(5):5-7.

3. Vasconcellos-Silva PR, Castiel LD, Rivera FJU. Assessing an Internet health infor- mation site by using log analysis: the experience of the National Cancer Institute of Brazil. Rev Panam Salud Publica. Forthcoming 2003.

4. Goldstein A, Balz D. Universal health care gets boost; Democratic rivals push new plans. Washington Post 2003 May 26:A1.
5. Adams G. Supporters celebrate as Dirigo Health bill signed. Portland Press Herald 2003 June 19. Available at: http://www. pressherald.com/news/statehouse/ 030619ap.shtml [Web site]. Accessed 19 June 2003. 